\title{
Tax Incentives for Supporting Competitiveness of Telecommunication Manufacturers
}

\author{
Irina Dezhina \\ Head, Science and Technology Development ${ }^{\mathrm{a}}$; Professor, Department of Innovation Management ${ }^{\mathrm{b}}$, i.dezhina@skoltech.ru
}

\author{
Tamam Nafikova
}

Analysta , t.nafikova@skoltech.ru

Timur Gareev

Deputy Head, Department of Science and Technologya, t.gareev@skoltech.ru

\begin{abstract}
Alexey Ponomarev
Vice-President for industrial development ${ }^{\text {a }}$; Professor, Department of Educational Programmes of the Institute for Statistical Studies and Economics of Knowledge (ISSEK) ${ }^{\mathrm{b}}$, ponomarev@skoltech.ru
\end{abstract}

\begin{abstract}
a Skolkovo Institute of Science and Technology, 30, bld. 1, Bolshoy Bulvar, Innovation Center 'Skolkovo', Moscow 121205, Russian Federation

${ }^{\mathrm{b}}$ National Research University Higher School of Economics (NRU HSE), 11 Myasnitskaya str., Moscow 101000, Russian Federation
\end{abstract}

\begin{abstract}
$\mathrm{T}$

he article is dedicated to the analysis of cost factors, primarily tax burden, that can explain the observable price differences on the Russian market between domestic telecommunication equipment and imports from China and USA. The relevance of the research is justified by the critical significance of this market for the economic, information, and technological security of the Russian Federation in a changing geopolitical environment. The present methods of tax burden calculation analyzed in this article revealed the sub-industry level measurement is the least studied. Based on data on 42 companies for 2015-2017, the cost structure of the telecommunication equipment manufacturing industry was studied, a model for computing the tax burden rate on domestic enterprises using imported components was built. The model was adjusted for a crosscountry comparison to reflect the specifics of countries' tax systems. The calculations were based on the assumption of equal production costs in the three countries under

examination. A comparative analysis showed that the tax burden in Russia is on average higher than in USA (almost 3 percentage points) and in China for enterprises operating in preferential economic zones (about 2 percentage points). However, this difference in tax burden rate does not explain the observed price discrepancy on the domestic market (up to 21 percent). The cost of components and cost of debt are additionally examined as factors that elucidate the divergence between economic conditions. An approximate assessment of their influence showed that the effect of reducing average costs with an increase in output of components, which is especially characteristic of China, has the largest impact. For American exporters, the tax burden level and high-end offers are the main competitive advantages. A number of tariff regulation measures that allow one to compensate for the price discrepancy on the domestic market are proposed for innovation policy in order to stimulate the technological development of national producers.
\end{abstract}

\section{Keywords:}

tax burden; competitiveness; economic sector; telecommunication equipment; Russia; China; United States; regulation
Citation: Dezhina I., Nafikova T., Gareev T., Ponomarev A. (2020) Tax Incentives for Supporting Competitiveness of Telecommunication Manufacturers. Foresight and STI Governance, vol. 14, no 2, pp. 51-62. DOI: $10.17323 / 2500-2597.2020 .2 .51 .62$ 
$\mathrm{T}$ he objective of creating a tax regime that would be favorable for companies' operations, strengthen their market competitiveness, and contribute to implementing the state's fiscal policy is relevant for many of the world's economies. A major characteristic of such a regime is the tax burden, usually understood as the combined share of all tax payments in the income of the economic actor under consideration. However, there are many nuances associated with the relevant indicators and methods for their calculation. A wide variety of relevant research areas at the international and national levels are represented in Figure 1.

The tax burden calculation techniques applied by the Organisation for Economic Cooperation and Development (OECD) and the International Monetary Fund (IMF) are believed to be the most highly developed and widely accepted, including those for international comparison purposes [Hanappi, 2018; Modica et al., 2018; International Monetary Fund, 2014]. In Russia, the tax burden is calculated by the Russian Ministry of Finance [Ministry of Finance, 2016] and the Federal Tax Service (FTS) ${ }^{1}$ using different methods. This paper analyzes the impact of tax burden upon a particular industry segment and upon Russian manufacturers' competitiveness compared with foreign manufacturers or exporters of similar products into Russia. The area under consideration remains insufficiently researched since the bulk of relevant studies are devoted to macroeconomic analysis Further, when it comes to specific industries, comparisons are made only between exporters [Xu, 2017].

Our study examines the tax burden in the relatively narrow, but critically important segment of the radio-electronic and electronic industry: the production of telecommunications equipment (TCE). This choice is due to several reasons. Firstly, the promotion of the domestic production of TCE is a national-level priority reflected in, among other initiatives, the measures to promote the application of domestic TCE in the framework of the national project "Digital Economy" 2 . This segment stands out among the related economic activity types even by the level of regulation: the Russian TCE register is approved by the national government ${ }^{3}$. However, despite the various incentives introduced in public procurement, ${ }^{4}$ the current development level and structure of the domestic TCE market do not meet strategic goals. In 2017, this market reached 465 billion rubles (less than 5\% of global value [RSpectr, 2018]), while according to various estimates, the share of imported equipment in Russia remains between $92 \%$ and $95.5 \%$ [Zhukova, Novy, 2019; RSpectr, 2019; J'son \& Partners Consulting, 2018].

The revision of initiatives to support domestic manufacturers in July 2019 resulted in the creation of a unified register of Russian radio-electronic products with increased contract price benefits over foreign public procurement participants proposals between $15 \%$ and $30 \%$ for state-owned companies ${ }^{5}$. However, despite being extremely important for promoting the development of the TCE market, this measure still has not solved all of the problems since the companies with public participation make up a smaller share of consumers on this market.

The term "inverted duty structure" used by certain researchers ${ }^{6}$ can be applied to describe the situation on the Russian market, with import duties for end-user equipment set at a lower level than those for the components with which this equipment is made of (see, e.g., [Pathania, Bhattacharjea, 2020]). This policy distorts incentives, encouraging Russian consumers to import ready-made equipment rather than step up their innovative activities. Given the new round of telecommunications development associated with the introduction of $5 \mathrm{G}$ networks and the need to ensure the security of data transmission systems, the creation of domestic technological solutions by domestic TCE manufacturers is becoming particularly relevant.

Against the background of protectionist measures being taken to insulate the national TCE markets, especially from Chinese manufacturers, the issue

Attachment No. 3 "Tax burden by economic activity type" to the Russian FTS Order of 30.05.2007 N MM-3-06/333@ (as amended on 10.05.2012) "On approving the On-site tax audit planning system concept". Available at: http://www.consultant.ru/document/cons_doc_LAW_55729/22fed7b20490780f0ca $2 \mathrm{ecae} 1005 \mathrm{c} 2 \mathrm{~b} 8 \mathrm{c} 36 \mathrm{e} 2 \mathrm{fbe} /$, accessed on: 05.03.2019.

RF Government Instruction No. MA-P10-8bpr of 18 December 2018 "On the decisions following the meeting on applying domestic telecommunications equipment to implement the measures specified in the national programme and the national project "Digital Economy"'. Available at: http://government. $\mathrm{ru} /$ orders/selection/401/35355/, accessed on 11.03.2019.

Available at: http://minpromtorg.gov.ru/opendata/?cat_38=15, accessed on 11.03.2019.

${ }^{4}$ RF Government Regulation No. 968 of 26 September 2016 "On restrictions on, and conditions for allowing application of certain types of radio-electronic products originating from foreign countries for the purpose of procurement to meet public state and municipal needs". (Available at: http://www.garant. $\mathrm{ru} /$ products/ipo/prime/doc/71400660/, accessed on 11.03.2019) and No. 925 of 16 September 2016 "On priority application of products and services of Russian origin in relation to products originating from a foreign country, and services provided by foreign persons" (available at: https://rg.ru/2016/09/27/ tovari-dok.html, accessed on 11.03.2019).

RF Government Regulation No. 878 of 10 July 2019 “On measures to promote production of radio-electronic products on in the Russian Federation when procuring products and services to meet public and municipal needs; on amending the RF Government Regulation No. 925 of 16 September 2016 , and invalidating certain RF Government acts" Available at: http://www.consultant.ru/document/cons_doc_LAW_329382/92d969e26a4326c5d02fa79b8f9cf499 4ee5633b/, accessed on 20.07.2019.

${ }^{6}$ For the most precise and brief definition of the term, see: https://howtoexportimport.com/Meaning-of-Inverted-duty-structure-9244.aspx, accessed on 24.03.2020. 
of the tax burden on this segment has acquired an international aspect. India began to pursue an active policy in this area, increasing import duties for several types of trunk TCE in 2018: up to $20 \%$ for optical networks, base stations, MIMO/4G LTE, and from $0 \%$ to $10 \%$ for printed circuit board electronic modules [FE Online, 2018]. Another example is the actions of the US government, which is preparing grounds to introduce a $25 \%$ duty for a number of TCE products to restrict Chinese imports [USTR, 2018].

Thus, a comparative analysis of the tax burden is important to better understand its impact upon the competitiveness of domestic TCE manufacturers.

\section{Existing Approaches to Calculating the Tax Burden}

A review of studies devoted to tax burden calculation techniques for various types of comparisons, regardless of the indicator aggregation degree, confirmed the lack of consensus among their authors. In particular, uncertainty remains about issues such as the classification of payments, classifying some of them as tax payments, and the choice of income indicators. For example, the OECD classifies compulsory social insurance contributions as taxes, while the IMF does not [Gromov, Shatalova, 2017]. According to the tax quota methodology applied by the IMF and the Russian Ministry of Finance to calculate the tax burden in the national economy, GDP is considered income, which in this context also seems to be debatable. [Sokolov, 2018] disputes the relevance of calculating tax revenue in relation to GDP in order to assess the tax burden in Russian economic realities and proposes the calculation of the burden on individuals and legal entities separately.

In a larger-scale industry breakdown, the Russian FTS's experience seems to be useful: it calculates tax burden as the ratio of the amount of paid taxes (reflected in official reports) and the organization's revenue according to the Federal State Statistics Service (Rosstat) data ${ }^{7}$. However, this approach does not allow one to take industry-specific aspects of taxation into account [Nikolaev, 2016]: for example, the TCE production segment is not present in the FTS industry classification because it is included in the "production of electrical equipment, computers, electronic and optical products" economic activity with a tax burden of $9.9 \%$. Treating a specific segment as an entire industry seems to be a gross distortion.
When calculating the size of tax payments, the FTS does not take into account the specifics of customs and tariff regulations, plus this calculation, among other things, excludes insurance premiums when calculating personal income tax (PIT). This does not seem to be entirely legitimate since the actual burden of paying this tax is borne by workers, while enterprises, although acting as tax agents, include the amount of PIT they have paid in their production costs (as part of the labor costs). The situation with insurance premiums is the opposite: in this case, the transfers to the state budget is an additional net tax burden upon manufacturers. As a measure of profit, the FTS uses revenue, not value created (i.e., value added minus depreciation) because the Russian Ministry of Economic Development insists upon this approach [Petlevoy et al., 2019]. Meanwhile, $\mathrm{PwC}$ correlates the amount of tax payments and social insurance contributions with the pre-tax profit [PwC, World Bank Group, 2018; PwC, 2016]. Obviously, several competing methodologies for calculating the tax burden exist and the advantages of some over others have not been convincingly proven yet.

Among the indicators applied to measure tax burden in the international comparisons context, the effective average and marginal tax rates the OECD uses $^{8}$ should be noted [Sorensen, 2004]. The effective average tax rate (EATR) is calculated as the ratio of tax payments to the value of the taxpayer's pre-tax surplus; it allows one to analyze the tax burden for various production factors and on specific entities in order to compare various tax jurisdictions or technological products [Hanappi, 2018]. The marginal effective tax rate (METR) indicator is the ratio of the difference between the expected return margin before and after tax to the pre-tax margin [Fullerton, 1999]. METR is applied to assess investment decisions by analyzing tax incentives' effects on the growth of investments in specific geographical areas. Both these techniques are more suitable either for highly aggregated data or for the evaluation of specific projects.

Another group of studies on approaches to tax burden calculation focus on assessing the consequences of introducing tax benefits, including those for research and innovation activities. These studies are of both qualitative (assessing the relevance of tax benefits and the extent of their application by companies) and quantitative nature, for example, when their authors consider the effect of such benefits upon the effective tax rate [Bornemann et al., 2019; Evers et al., 2015]. In particular, tax incen-

\footnotetext{
7 Attachment 2 "Publicly available criteria for self-assessment of risks for taxpayers applied by tax authorities to select taxpayers for on-site tax audits" to the Russian FTS Order of 30.05.2007 N MM-3-06/333@ (as amended on 10.05.2012) "On approving the On-site tax audit planning system concept". Available at: http://www.consultant.ru/document/cons_doc_LAW_55729/f579efc1e846c86acedf1433b3fb8817a96a6916/, accessed on: 05.03.2019.

${ }^{8}$ OECD Statistics. Effective Tax Rates database. Available at: https://stats.oecd.org/Index.aspx?DataSetCode=CTS_ETR, accessed on 13.03.2019.
} 


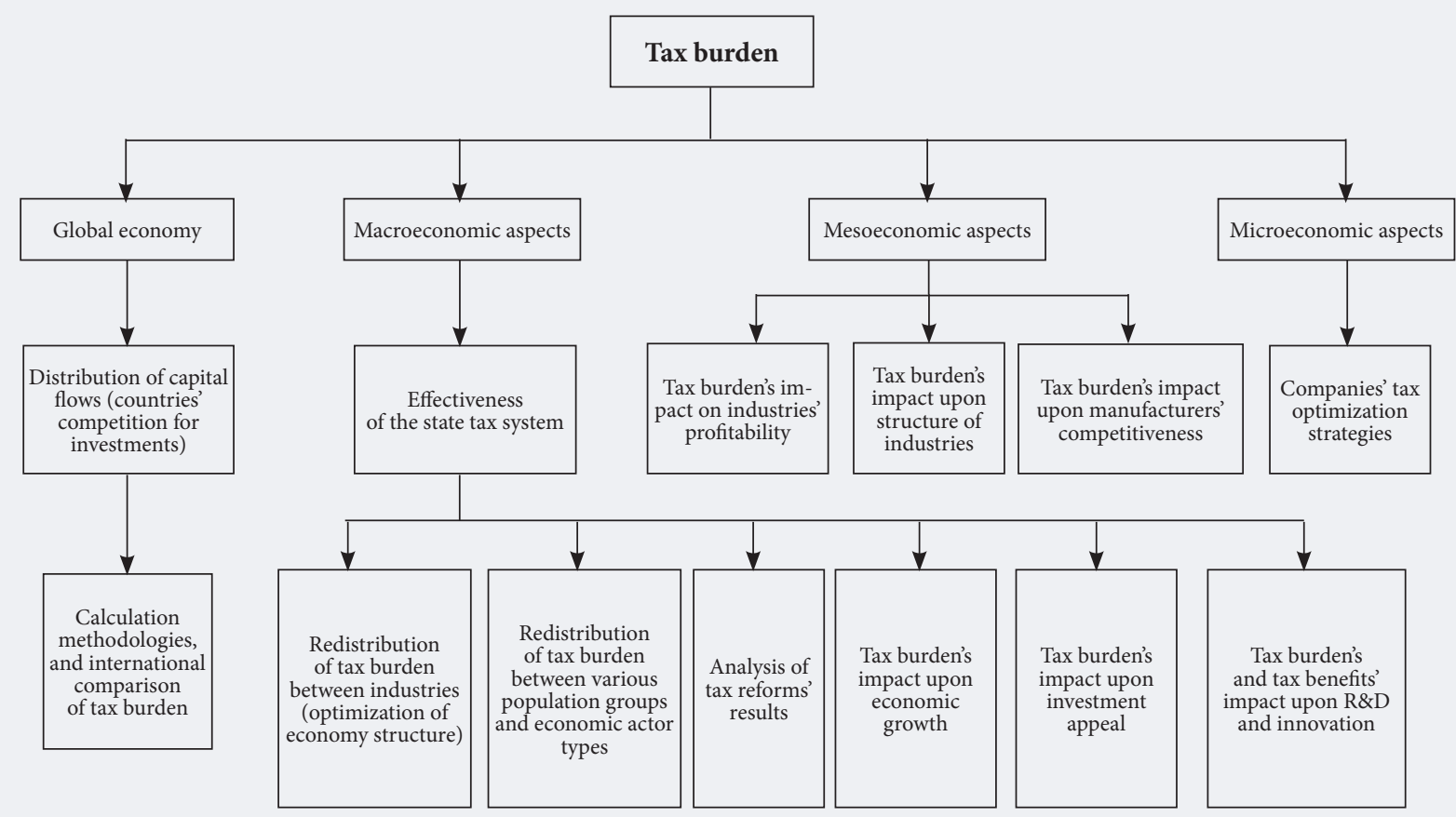

Source: compiled by the authors.

tives include increasing depreciation rate coefficients, the application of similar coefficients to the actual research and development (R\&D) expenditures, the exemption of certain priority activities from VAT, and incentives made available in free and special economic zones. Studies based on Russian data indicate that demand for tax benefits is low, including for those related to R\&D [Kitova, 2015; Gokhberg et al., 2014; Vlasova et al., 2018]. The main reasons include the insufficient transparency of the system, in particular, the significant costs of substantiating one's right to receive benefits, the high risks of disputes with tax authorities, and administrative prosecution. The situation with tax benefits abroad is much more favorable. In particular, in China many TCE manufacturers are located in areas where preferential regimes exist.

\section{The Choice of Countries for Comparison}

The countries with which to compare the tax burden were selected by analyzing the structure of TCE imports into Russia using the Federal Customs Service (FCS) database ${ }^{9}$. The geographic structure of imports (Figure 2) indicates that Chinese manufacturers are the main competitors to Russian ones on the domestic market. In its turn the US, despite being a traditional technology leader, lags more than ten times behind China in this segment. These two competing countries became the objects of our comparison.

In China, telecommunications products have been included in special registers since 2006, which allows companies to apply for preferential tax rates, cheap loans from state banks, and subsidies for export credit insurance. In 2009, the Radio Electronics Industry Restructuring and Revitalising Plan was adopted in the country, which provides for tax incentives to promote export operations [McCarthy, 2012]. Meanwhile China remains the biggest TCE supplier in the world: the two leading companies, Huawei and ZTE, in 2018 accounted for $37 \%$ of the global market [Pongratz, 2019] which has reached $\$ 175$ billion [Burkitt-Gray, 2019)].

On the contrary, the US does not apply any special measures to support domestic TCE manufacturers, so the country's international competitiveness is based upon the general economic conditions for doing business, a high level of technological competencies in the industry, and the historical dominance of the US company Cisco in the corporate segment. Together with

\footnotetext{
9 The calculation was conducted using the foreign economic activity commodity nomenclature (FEACN) codes, specifically subheadings 8517620002,8517 620003 , and 8517620009.
} 
another American player, Ciena, they control about $13 \%$ of the global market ${ }^{10}$.

\section{Tax Burden Calculation Model}

For international comparisons in the industry, a less sensitive approach to companies' national specifics was chosen, under which the tax burden is calculated as the ratio of tax payments to profit. Taking into account the availability of statistical data, company revenue was chosen as the profit measure.

Indicator types were selected on the basis of the following criteria:

- the number of indicators should not be excessively large or complicate calculations, since the main objective was to compare the tax burden upon manufacturers in different jurisdictions in a minimally reliable way, not to calculate its exact level;

- calculations should be based upon the available statistical data, therefore the initial sample of companies was built using the SPARK database (companies' financial statements section). To calculate the average weighted customs duty rates, the Eurasian Economic Union single customs tariff ${ }^{11}$ was used to determine the rates for the selected FEACN codes, and the Russian FCS database was the source of data on imports of products with relevant codes.

Payments taken into account to calculate the tax burden included profit tax, VAT, and social insurance contributions, but not personal income tax which defines the tax burden on workers rather than manufacturers. Although VAT is passed on to the buyer via the pricing mechanism, it still should be taken into account since prices higher than those of imported products reduce the competitiveness of domestic ones. Finally, the fact of paying customs duties is important for a comparative analysis, so they were also taken into account to calculate the tax burden.

In the absence of ready-made measurements for the TCE production segment (which was revealed by the analysis of tax burden sources), data on manufacturing companies was used. Data from 2015-2017 financial statements of TCE manufacturers engaged in the following OKVED activities was downloaded from the SPARK database:
- production of communication equipment;

- production of communication equipment, radio and television transmitting equipment, television cameras;

- production of radio and television transmitting equipment;

- production of communication equipment with switching systems functionality;

- production of spare parts and components for radio and television transmitting equipment and television cameras;

- production of other telephones, devices, and equipment for transmitting and receiving speech, images, or other data, including communication equipment for wired or wireless communication networks (e.g. local and global networks);

- production of computers and peripheral equipment;

- production of electronic components.

According to long-term observations of relevant industry associations such as the Association of Electronics Developers and Manufacturers (AEDM) and the Information and Advanced Electronics Analytical Centre [ARPE, 2019], there are between 60 and 80 developers and manufacturers of civilian TCE in Russia. In total, data on 62 companies for 2015-2017 was collected. Due to the gaps in the panel data, the final sample com-

\section{Figure 2. Major TCE Exporters to Russia (FEACN subgroups 8517 62)}

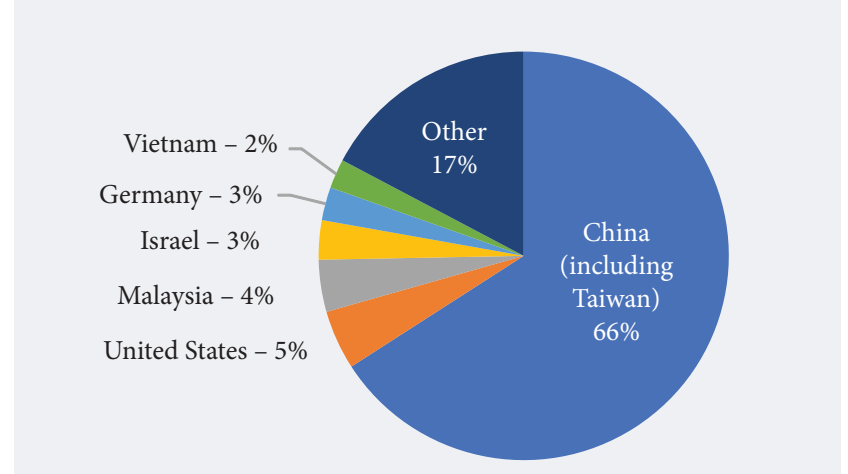

Source: calculated by the authors based on the Russian FCS customs statistics of foreign trade. Available at: http://stat.customs.ru/apex/ $\mathrm{f} ? \mathrm{p}=201: 2: 4201345773515950:: \mathrm{NO}$, accessed 08.03.2019.

\footnotetext{
${ }^{10}$ For more about the TCE market, see relevant industrial reports, e.g. [Market Research Future, 2019].

${ }^{11}$ Attachment to the decision of the Council of the Eurasian Economic Commission of 16.07.2012 No. 54 (as amended on 22.02.2019) "Common Customs Tariff of the Eurasian Economic Union”. Available at: http://www.consultant.ru/document/cons_doc_LAW_133133/22ad39bb36d3b8a63d493b0be82dc71 $70 \mathrm{c} 9 \mathrm{f} 82 \mathrm{f} 6 /$, accessed on 05.03.2019.
} 
prised 42 companies. A total of 102 observations were analyzed, which ensures the robustness of the results. The presented sample is not only representative but sufficiently complete, since it includes observations on all major players in the highly concentrated Russian TCE production segment (Table 1).

The number of observations varied in terms of revenue, profit, and tax indicators, so to calculate the tax burden on Russian companies, the data was supplemented. Tax burden was defined as the ratio of the total amount of income tax, VAT, social in surance contributions, and customs duties paid to the total revenues.

Subsequent calculations were based on the following assumptions:

- Russian manufacturers import all components while they make modules and end-user equipment at their own facilities; development and marketing are carried out by third-party organizations within the country.

- Manufacturers in Russia and the US pay taxes at standard rates and do not use tax optimization techniques such as moving production to special economic zones or using other tax benefits; Chinese manufacturers can either pay standard taxes or use special preferential rates (both options will be considered).

- All tax systems under consideration are effective: if the tax system provides for VAT refunds for export-import operations, it is assumed that all participants on the relevant markets can freely and fully exercise this right.

- Logistical costs were not taken into account, but the cost of domestic equipment was, compared with the cost of foreign counterparts taking into account customs duties for products imported into Russia.

- Profit rates, components' and services' costs, and labor costs are the same in all countries and correspond to the model parameters for Russia. Each of these indicators is calculated as the ratio of total costs for all observations to total revenue for the entire sample.

- Customs duties were calculated using weighted average rates. For electronic components, they were calculated using the AEDM data on the cost structure of electronics production, compiled on the basis of a study of the Russian market and relevant equipment manufacturers
[ARPE, 2017], plus customs statistics on the import of relevant FEACN subheadings ${ }^{12}$. The weighted average rate for imported equipment was calculated using customs statistics only. The weighted average customs duty for components amounted to $2.1 \%$, and for end-user equipment $0 \%$.

- Taking into account the AEDM data and the weighted average customs duty rate, it was assumed that in the structure of payments to suppliers and contractors, components (including customs duties) account for about 2/5 of the total costs, and services received within the country for $3 / 5$.

- To calculate VAT, sales revenues and labor costs (including insurance premiums) were taken as value added (VA).

The above assumptions were necessary because studies such as ours imply specific estimates of random indicators (at the level of their mathematical expectations). In a more general case, we get a set of random value distributions whose ranges are limited by balanced proportions.

Also, the above assumptions balance the short-term random deviations of the applied indicators and the long-term effect of leveling the overall economic conditions the companies operate in. To eliminate the effect of the general taxation regime, the principle "all other conditions being equal" was applied, since otherwise any model would only reflect particular indicator fluctuations (as opposed to the integral effect). In reality, companies' profitability and other cost indicators are sufficiently varied. However, the likely inaccuracies in the assumptions made were not critically important to the results of the study. For example, the logic of economic balances does not allow even significant outliers to upset the balance of the system of indicators in the long term, due to the high competition on the TCE market. If a company buys components at a price much lower than the market average and thus obtains a competitive advantage, this factor will be leveled in the next accounting period. The specifics of the telecommunications market is such that it actively applies the rapid expansion strategy in the hope of receiving long-term payback due to network effects and "lock-in" mechanisms. Such measures include direct dumping, transfer pricing [Gareyev, 2008], and soft loans to consumers at the time of generational equipment replacement at customers' facilities. Plus, as was noted, the assumptions we made were of an averaging nature.

\footnotetext{
${ }^{12}$ The weighted average customs duty is calculated for the AEDM-identified component types (microcircuits, discrete semiconductors, passive elements, electromechanical components). Since each component type corresponded to several FEACN codes, before calculating the total weighted average rate it was necessary to determine it for each specific type. In the framework of each component type, a separate FEACN code was assigned a weight proportional to its share in total imports, in monetary terms. Then each component type was weighted by its share in the cost structure calculated on the basis of AEDM.
} 


\section{Table 1. Production Concentration Coefficients ${ }^{\star}$ by Economic Activity Type in the TCE Production Segment, 2017 (\%)}

\begin{tabular}{|c|c|c|}
\hline Types of economic activities & For 25 companies & For 50 companies \\
\hline Production of communication equipment & 91.62 & 99.87 \\
\hline $\begin{array}{l}\text { Production of communication equipment, radio and television transmitting } \\
\text { equipment, television cameras }\end{array}$ & 94.75 & 100 \\
\hline Production of communication equipment with switching systems functionality & 100 & 100 \\
\hline Production of radio and television transmitting equipment & 99.92 & 100 \\
\hline \multicolumn{3}{|c|}{$\begin{array}{l}\text { * Share of a certain fixed number of enterprises in the activity type, ranked by size, in descending order. } \\
\text { Source: Unified interdepartmental information and statistical system (UIISS) (2019). Production concentration coefficients by economic activity type } \\
\text { since } 2017 \text {. Available at: https://fedstat.ru/indicator/58999, accessed on 20.07.2019. }\end{array}$} \\
\hline
\end{tabular}

Thus, the formula for a simplified calculation of the tax burden on Russian manufacturers who use imported components is as follows:

$$
\begin{aligned}
& \text { Tax burden }{ }_{\text {nat }}= \\
& =\frac{\left[t_{\pi} \sum \pi+t_{\text {vat }} \Sigma(\pi+\mathrm{OT})+\frac{t_{S}}{1+t_{S}} \Sigma \mathrm{OT}\right]+d_{\mathrm{K}} \Sigma \mathrm{K}}{\sum R}
\end{aligned}
$$

where $\pi$ is sales revenue;

$t_{\pi}$ is profit tax rate;

$t_{\text {vat }}$ is VAT rate;

$O T$ is labor costs (including social insurance);

$t_{s}$ is social insurance premium rate;

is the value of components (without customs duties);

$d_{K}$ is weighted average customs duty for components;

$R$ is revenue.

To calculate the tax burden on manufacturers of imported end-user equipment, the formula must be adjusted taking into account two main factors. First, the Chinese and US tax systems have their own specific features: in China, as in most countries of the world, the value of exported goods is cleared of VAT accrued within the country; in the US, not VAT but sales tax is applied to goods and services, but not to exported goods. When equipment from both China and the US is imported into Russia, VAT is charged for the cost of the goods

\section{Table 2. TCE Manufacturing Industry Ratios}

\begin{tabular}{|l|c|}
\hline \multicolumn{1}{|c|}{ Indicator } & Value (\%) \\
\hline Sales revenues rate $(\pi / \mathrm{R})$ & 9.6 \\
\hline Labor costs rate $(\mathrm{OT} / \mathrm{R})$ & 27.1 \\
\hline $\begin{array}{l}\text { Component costs rate excluding customs } \\
\text { duties (K/R) }\end{array}$ & 24.2 \\
\hline Source: compiled by the authors. & \\
\hline
\end{tabular}

and customs duties at the rate set by Russian law. Secondly, unlike domestic manufacturers for whom the duty is charged for components, for importers of foreign equipment the calculation formula takes into account the value of equipment.

Accordingly, the formula for calculating the tax burden on manufacturers of imported equipment looks as follows:

$$
\begin{aligned}
& \text { Tax burden }_{\text {im }}= \\
& =\frac{\left[t_{\pi} \sum \pi+t_{\text {vat }}\left(1+d_{\mathrm{o} 6}\right) \sum(\pi+\mathrm{OT})+\frac{t_{S}}{1+t_{S}} \sum \mathrm{OT}\right]+d_{\mathrm{o} 6} \sum R}{\sum R}
\end{aligned}
$$

where is weighted average customs duty for imported equipment.

In line with the assumptions made, the following indicator values were obtained, calculated as the ratio of the respective indicators' total values to the total revenue for the entire sample (Table 2).

By normalizing the revenue figures and using the above industry proportions, we obtain the following formula for calculating the tax burden on Russian TCE manufacturers:

$$
\begin{aligned}
& \text { Normalized tax burden }_{\text {nat }}= \\
& =\left[9.6 t_{\pi}+36.7 t_{\text {vat }}+27.1 \frac{t_{s}}{1+t_{s}}\right]+24.2 d_{\mathrm{K}}
\end{aligned}
$$

\section{Comparing Tax Burdens}

Based on the obtained simplified model, the tax burden was calculated for the Russian (component importers), Chinese, and American (end-user product manufacturers exporting to Russia) TCE segments. The tax rates for 2017 were applied. The profit tax and compulsory social insurance rates in the US and China were taken from the KPMG (audit and consulting company) database ${ }^{13}$. An additional scenario was calculated for China: apply-

\footnotetext{
${ }^{13}$ Employer social security tax rates (https://home.kpmg/xx/en/home/services/tax/tax-tools-and-resources/tax-rates-online/social-security-employer-taxrates-table.html, accessed on 12.03.2019), and corporate tax rates table (https://home.kpmg/xx/en/home/services/tax/tax-tools-and-resources/tax-ratesonline/corporate-tax-rates-table.html, accessed on 12.03.2019).
} 
Table 3. Tax Burden on the Russian TCE Manufacturing Segment, Chinese and US Exporters (\%)

\begin{tabular}{|l|c|c|c|c|}
\hline \multicolumn{1}{|c|}{ Indicator } & Russia & China & $\begin{array}{c}\text { China (preferential } \\
\text { regime) }\end{array}$ & US \\
\hline VAT rate* & 18.0 & 18.0 & 18.0 & 18.0 \\
\hline Profit tax rate & 20.0 & 25.0 & 15.0 & 40.0 \\
\hline Social insurance premium rate & 30.2 & 33.9 & 23.5 & 7.7 \\
\hline Weighted average tax duty on components & 2.1 & - & - & - \\
\hline Weighted average tax duty on equipment & - & 0.0 & 0.0 & 0.0 \\
\hline Tax burden & $\mathbf{1 5 . 3 1}$ & $\mathbf{1 5 . 8 7}$ & $\mathbf{1 3 . 2 0}$ & $\mathbf{1 2 . 3 9}$ \\
\hline Difference with Russia & - & $\mathbf{+ 0 . 5 6 \%}$ & $\mathbf{- 2 . 1 1 \%}$ & $\mathbf{- 2 . 9 2 \%}$ \\
\hline
\end{tabular}

Note: ${ }^{\star}$ Russian VAT rate is shown for China and the US, since these countries do not apply VAT/sales tax to exports and Russia taxes imports at the domestic VAT rate.

Source: compiled by the authors.

ing benefits widely available in special economic zones and reduced (to 15\%) income tax rates for high-tech companies. For province-level social insurance contributions [Van't Klooster, 2018], the Shenzhen rate was applied, where the key TCE manufacturers Huawei and ZTE are located.

Based on these assumptions, the following tax burden was calculated for each country (Table 3 ).

All other things being equal, the tax burden in Russia turns out to be higher than in the US but lower than in China, provided companies there do not use a preferential tax regime. Apparently, most Chinese companies supplying TCE to Russia use the benefits and special provisions for exporting products abroad (or the advantages provided by a different cost structure).

An analysis of specific taxation components (Table 4) shows that, based on the assumption all countries have the same added value rate, the difference in VAT for producers is leveled. This is explained by the zero weighted average customs duty (increasing it by $1 \%$ leads to the tax burden on imported equipment (VAT) growing by $0.1 \%$ ). In terms of profit tax and social insurance contributions, Russia is second only to the preferential regime in China (higher by $0.5 \%$ and $0.8 \%$, respectively). In the US, the burden of providing a social safety net falls on individuals, so the difference here is enormous, at $4.4 \%$. Finally, because of the already mentioned "inverted duty structure" foreign manufacturers are relieved of this burden, while domestic enterprises do have to pay duties, albeit relatively modest ones in terms of the overall tax burden.

\section{Discarding the "Ceteris Paribus" Condition for Production Costs}

Our analysis of the tax burden based on the "all other things being equal" (ceteris paribus) con- dition assumed that the production costs in the three countries under consideration were the same. However, they are affected by several other factors which ultimately determine companies' competitiveness:

- cost saving due to economies of scale;

- cost of credit;

- organization of production.

Since the organization of production depends upon many individual factors which are difficult to take into account even when comparing enterprises in one country, assessing its impact on the competitiveness of industries in several countries is extremely difficult. Production of components does allow one to save costs through economies of scale [Hsu, Li, 2009]. Reduced average costs due to increased output allow one to sell products at a lower price. Figure 3 shows this effect for integrated circuits production in Russia and China. The graph clearly illustrates the significant difference in the production costs of this component type: the cost of production in Russia is 2.4-3.6 times higher than in China (depending on the amount of fixed costs).

Table 4. Shares of Specific Taxes in the Overall Tax Burden on the Russian TCE Manufacturers, Chinese and US Exporters (\%)

\begin{tabular}{|c|c|c|c|c|}
\hline Indicator & Russia & China & $\begin{array}{l}\text { China } \\
\text { (with } \\
\text { benefits) }\end{array}$ & US \\
\hline VAT & 6.6 & 6.6 & 6.6 & 6.6 \\
\hline Profit tax & 1.9 & 2.4 & 1.4 & 3.9 \\
\hline $\begin{array}{l}\text { Social insurance } \\
\text { premiums }\end{array}$ & 6.3 & 6.9 & 5.1 & 1.9 \\
\hline Customs duties & 0.5 & 0.0 & 0.0 & 0.0 \\
\hline Overall tax burden & 15.31 & 15.87 & 13.20 & 12.39 \\
\hline
\end{tabular}




\section{Figure 3. Integrated Circuit Production Costs in Russia and China}

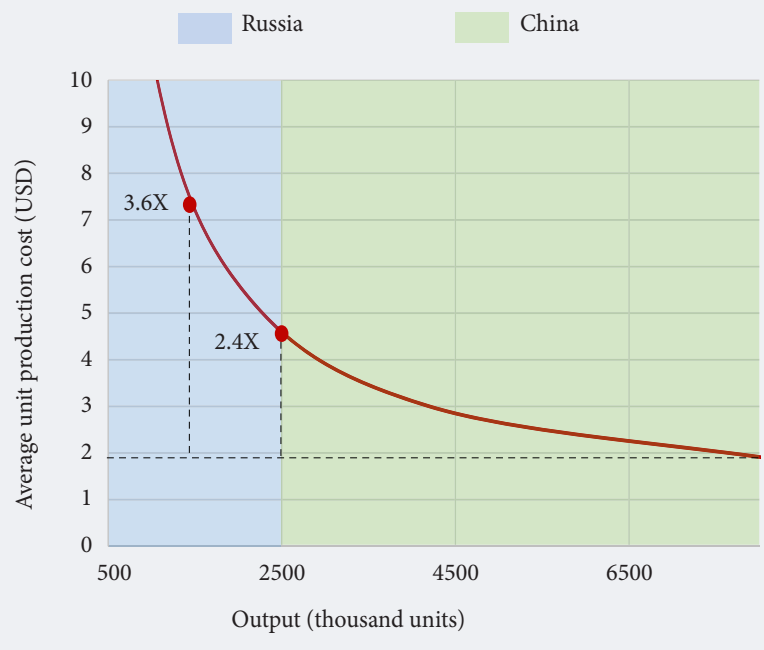

Source: calculated by the authors based on the Unified interdepartmental information and statistical system (UIISS) "Production concentration coefficients by economic activity type (in line with the OKPD2)" (https:// www.fedstat.ru/indicator/58998, accessed 13.03.2019) and "Production of main product types in physical terms since 2017 (in line with the OKPD2)" (https://www.fedstat.ru/ indicator $/ 58636 ? \mathrm{id}=58636$, accessed 13.03.2019); and [PRNewswire, 2019; Kolomychenko, 2017; $\mathrm{Hsu}, \mathrm{Li}, 2009]$.

The observed gap in components' production costs can result in a significant difference in end-user equipment prices (Figure 4). Taking into account our earlier analysis of industry proportions and the AEDM data on the components' production costs structure, integrated circuits account for $12.1 \%$ of the end product price. Accordingly, just the integrated circuit production cost factor in Russia and China accounts for between $7 \%$ and $8.7 \%$ of the difference in TCE prices.

The second factor affecting production costs is the cost of credit, which depends upon interest rates. In Russia they are significantly higher than in the US and China: $10.56 \%$ versus $3.9 \%$ and $4.35 \%{ }^{14}$, respectively. With the lowest share of credit in revenues at $18 \%$ [NDIA, 2017] and the highest at $33 \%{ }^{15}$, this factor's contribution to production costs of Chinese and American equipment ranges between $1.1 \%-1.2 \%$ and $2.0 \%-2.2 \%$, respectively.

\section{Conclusions and Areas for Further Research}

Calculating the tax burden in a specific industry is critical for assessing the economic conditions for companies' development and its relevance is all the higher the more actively the government pursues a targeted policy to support domestic production in strategic industries. However, in the case of a specific industry segment, the analysis is complicated by the lack of a generally accepted methodology, including one for comparing the competitiveness of manufacturers in various jurisdictions.
The suggested approach allows one to calculate the tax burden on Russian TCE manufacturers taking into account the industry's specifics and compare it with similar indicators for manufacturers from China and the US who export their products to Russia. A comparative analysis of the tax burden and its components revealed that, all other things being equal, Chinese producers who enjoy preferential regimes operate in better economic conditions than Russian companies, due to lower profit tax rates and social insurance contributions, and so

Figure 4. Price Advantage of Imports from China over Russian Products due to Economies of Scale in Component Production

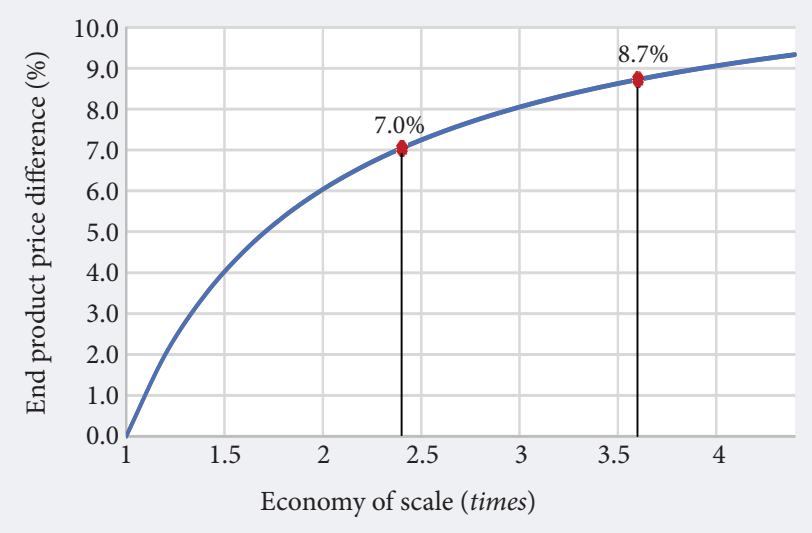

Source: compiled by the authors .

\footnotetext{
${ }^{14}$ The World Bank Development Indicators database. Available at: https://databank.worldbank.org/data/reports.aspx?source=2\&series=FR.INR. LEND\&country=\#, accessed on 03.04.2019

${ }^{15}$ An estimate based on data on Russian companies' accounts payable.
} 
do American firms, due to transferring the burden of social insurance to individuals which reduces the profit tax burden. A consistent shift in the tax burden from legal entities to individuals in the US is also noted by other authors [Sokolov, 2018; Grubert, Altshuler, 2015]. Customs duties play a large role too: in addition to directly affecting the overall tax burden, they have an indirect effect through the VAT calculation mechanism applied to imported equipment. Increasing customs duties on end-user equipment imported into the country may strengthen the competitiveness of Russian manufacturers.

However, possible steps to create favorable economic conditions for domestic telecommunications companies are not limited to introducing higher customs duties for foreign manufacturers. As the Chinese experience shows, the broad application of benefits allows one to significantly reduce the tax burden, that is, the development of domestic production can be facilitated by transferring it to areas where special preferential regimes apply.

Our calculations are of a demonstrative nature because they are based on a number of assumptions. Nevertheless, the suggested assessment methodology has a number of advantages which give grounds to count on its further application. After the circle of observed companies (sectors) is determined, the variance in observations decreases with each reporting cycle. There is potential to apply Bayesian methods for modeling random variables used in the model, which will allow one to calculate substanti- ated informative priors for related segments (electronics and radio electronics). In the medium term, this will allow one to assess the effects and contribution of taxation and other regulatory factors to the restructuring of the domestic TCE market.

A key assumption was considering the production ratios in all countries to be the same. However, manufacturers' cost structure in different countries is obviously different. When the variability of cost factors is included in the current model, the mathematical expectation of the highest percentage difference in production costs with Chinese equipment reaches $13 \%$, with the reduction of the average costs due to increased output accounting for two-thirds of that. Thus, Chinese manufacturers can significantly reduce the cost of components.

The factors considered here, despite their indisputable importance, cover only a few competitiveness parameters. Technological advantages, sensible company strategies, and global macroeconomic conditions such as the quality and efficiency of the tax system and the availability of capital, play equally important roles in strengthening companies' competitiveness.

The authors are grateful to Alexei Chernikov, Director General of Eltex Enterprise LLC, and Ivan Pokrovsky, Director of the Association of Russian Electronics Developers and Manufacturers (AEDM) for the provided materials and valuable comments made during the discussion and preparation of this paper. Any possible remaining errors and interpretations are the responsibility of the authors.

\section{References}

ARPE (2017) Otsenka reguliruyushchego vozdeistviya zagraditel'nykh tamozhennykh poshlin na rynok elektroniki [Assessment of the regulatory impact of barrage customs duties on the electronics market]. Available at: http://arpe.ru/activities/ lobbying-of-sectoral-interests/tamozhennoe-regulirovanie/, accessed 05.03.2019 (in Russian).

ARPE (2019) Proizvoditeli telekommunikatsionnogo oborudovaniya [Telecommunications equipment manufacturers]. Available at: http://www.sovel.org/spravochnik1/kompanii/\#n1146, accessed 21.07.2019 (in Russian).

Bornemann T., Laplante S.K., Osswald B. (2019) The effect of intellectual property boxes on innovative activity \& effective tax rates. WU International Taxation Research Paper Series, no 2018-03 (online). Available at: https://papers.ssrn.com/ sol3/papers.cfm?abstract_id=3115977, accessed 09.04.2019.

Burkitt-Gray A. (2019) Nokia and Ericsson flat in infrastructure market as Huawei hits 29\%, says Dell'Oro. Available at: https://www.capacitymedia.com/articles/3823275/nokia-and-ericsson-flat-in-infrastructure-market-as-huawei-hits29-says-delloro, accessed 20.07.2019.

Evers L., Miller H., Spengel C. (2015) Intellectual property box regimes: Effective tax rates and tax policy considerations. International Tax and Public Finance, vol. 22, no 3, pp. 502-530.

FE Online (2018) India to US: Can't remove customs duty on telecom gear; it will put unbearable stress on economy. Available at: https://www.financialexpress.com/economy/india-to-us-cant-remove-customs-duty-on-telecom-gear-it-will-putunbearable-stress-on-economy/1388451/, accessed 12.03.2019.

Fullerton D. (1999) Marginal Effective Tax Rate. The Encyclopedia of Taxation and Tax Policy, pp. 270-272. Available at: https://www.urban.org/sites/default/files/alfresco/publication-pdfs/1000538-Marginal-Effective-Tax-Rate.pdf, accessed 05.04.2019. 
Gareev T.R. (2008) Osnovy mezhdunarodnogo marketinga [Fundamentals of International Marketing], Kaliningrad: Immanuel Kant Baltic Federal University (in Russian).

Gokhberg L., Kitova G., Roud V. (2014) Tax incentives for R\&D and innovation: Demand versus effects. Foresight and STI Governance, vol. 8, no 3, pp. 18-41.

Gromov V.V., Shatalova S.S. (2017) Otsenka nalogovoi nagruzki po metodike MVF [Assessment of Tax Burden by a Technique of the IMF]. Upravlenčeskoe konsul'tirovanie / Administrative Consulting, no 1, pp.74-83 (in Russian).

Grubert H., Altshuler R. (2015) Shifting the burden of taxation from the corporate to the personal level and getting the corporate tax rate down to 15 percent. National Tax Journal, vol. 69, no 3, pp. 643-676.

Hanappi T. (2018) Corporate Effective Tax Rates: Model Description and Results from 36 OECD and Non-OECD Countries, Paris: OECD.

Hsu C.I., Li H.C. (2009) An integrated plant capacity and production planning model for high-tech manufacturing firms with economies of scale. International Journal of Production Economics, vol. 118, no 2, pp. 486-500. Available at: https:// ir.nctu.edu.tw/bitstream/11536/7435/1/000266478300012.pdf, accessed 25.03.2019.

International Monetary Fund (2014) Government finance statistics manual 2014, Washington, D.C.: International Monetary Fund. Available at: https://www.imf.org/external/np/sta/gfsm/index.htm, accessed 04.03.2019.

J'son \& Partners Consulting (2018) Atlas rynka telekommunikatsionnogo oborudovaniya rossiiskogo proiskhozdeniya (TORP) [Market Atlas for Telecommunivation Equipment of Russian Origin]. Available at: http://json.tv/ict_telecom_analytics_ view/atlas-rynka-telekommunikatsionnogo-oborudovaniya-rossiyskogo-proishojdeniya-20180227022931, accessed 11.03.2019 (in Russian)

Kitova G.A. (2015) Nalogovoe stimulirovanie nauki i innovatsii v Rossii: praktika i issledovaniya [Tax Incentives for Science and Innovation in Russia: Practice and Research], Moscow: HSE (in Russian).

Kolomychenko M. (2017) “Angstrem” prosyat osvobodit' nanometry [“Angstrem” is asked to free nanometers]. Kommersant Newspaper, no 79, p. 10. Available at: https://www.kommersant.ru/doc/3289550, accessed 14.03.2019 (in Russian).

Market Research Future (2019) Telecom Equipment Market Research Report - Global Forecast up to 2023. Available at: https://www.marketresearchfuture.com/reports/telecom-equipment-market-4441, accessed 20.07.2019.

McCarthy M.O. (2012) Background Material for US-China Economic and Security Review Commission. Available at: https:// www.uscc.gov/sites/default/files/6.14.12McCarthy.pdf, accessed 22.03.2019.

Ministry of Finance (2016) Osnovnye napravleniya nalogovoi politiki na 2017 god i planovyi period 2018 i 2019 godov [The main directions of tax policy for 2017 and the planning period of 2018 and 2019], Moscow: Ministry of Finance of the Russian Federation. Available at: https://www.minfin.ru/ru/document/?id_4=116206, accessed 13.03.2019 (in Russian).

Modica E., Laudage S., Harding M. (2018) Domestic revenue mobilisation: A new database on tax levels and structures in 80 countries, Paris: OECD.

NDIA (2017) Trustable Access to Leading Edge Technology. Available at: http://www.ndia.org/-/media/ sites/ndia/divisions/working-groups/tmjwg-documents/ndia-tm-jwg-team-2-white-paper-finalv3.ashx?la=en, accessed 27.03.2019.

Nikolaev I.A. (2016) Analiticheskaya otsenka nalogovoi nagruzki v rossiiskoi ekonomike [Analytical assessment of the tax burden in the Russian economy], Moscow: Committee of the RSPP on tax policy. Available at: https://www.fbk.ru/ upload/docs/nalogovaya_nagruzka.pdf, accessed 19.03.2019 (in Russian).

Pathania K., Bhattacharjea A. (2020). Inverted Duty Structures and the Paradox of Negative Effective Protection in India, 2000-2014. Foreign Trade Review. Available at: https://doi.org/10.1177/0972266119894131, accessed 24.03.2020.

Petlevoi V., Kholyavko A., Bazanova E., Trifonova P. (2019) Pravitel'stvo ne ostavlyaet popytok sobrat' bol'she deneg s biznesa [The government does not abandon attempts to raise more money from business]. Vedomosti, 29.01.2019. Available at: https://www.vedomosti.ru/economics/articles/2019/01/29/792760-s, accessed 21.07.2019 (in Russian).

Pongratz S. (2019) Key Takeaways - Worldwide Telecom Equipment Market 2018. Available at: https://www.delloro.com/ telecom-equipment-market-2018-2/, accessed 20.07.2019.

PRNewswire (2019) China Wafer Production Capacity Growth Fastest in World. Available at: https:/www. prnewswire.com/news-releases/china-wafer-production-capacity-growth-fastest-in-world-300773756.html, accessed 17.03.2019.

PwC (2016) The Total Tax Contribution Framework: Over a Decade of Development, London: PricewaterhouseCoopers. Available at: https://www.pwc.com/gx/en/tax/pdf/the-total-tax-contribution-framework.pdf, accessed 19.03.2019. 
PwC, World Bank Group (2018) Paying Taxes 2019. Washington, D.C.: PwC, World Bank, International Finance Corporation. Available at: https://www.pwc.com/gx/en/paying-taxes/pdf/pwc-paying-taxes-2019.pdf, accessed 12.03.2019.

RSpectr (2018) Menyayu chuzhoe na svoe [Changing Someone Else's for the Own]. Available at: https://www.rspectr.com/ articles/392/menyayu-chuzhoe-na-svoe, accessed 20.07.2019 (in Russian).

RSpectr (2019) Otechestvennye telekom-proizvoditeli poluchat l'goty [Domestic Telecommunication Producers Will Get Incentives]. Available at: https://rspectr.com/articles/476/otechestvennye-telekom-proizvoditeli-poluchat-lgoty, accessed 11.03.2019 (in Russian).

Sokolov M.M. (2018) Ob urovne nalogovoi nagruzki v ekonomike Rossii i o vozmozhnostyakh po ee snizheniyu bez sokrashcheniya nalogovykh postuplenii [On the level of the tax burden in the Russian economy and the possibilities to reduce it without reducing tax revenues]. Èkonomika $v$ promyšlennosti / Russian Journal of Industrial Economics, vol. 11, no 1, pp. 52-62 (in Russian).

Sorensen P.B. (2004) Measuring the tax burden on capital and labor, Cambridge, MA: Massachusetts Institute of Technology.

USTR (2018) Notice of Action and Request for Public Comment Concerning Proposed Determination of Action Pursuant to Section 301: China's Acts, Policies, and Practices Related to Technology Transfer, Intellectual Property, and Innovation. Federal Register, vol. 83, no 119, pp. 28710-28756. Available at: https://ustr.gov/sites/default/files/2018-13248.pdf, accessed 15.03.2019.

Van't Klooster M. (2018) Hiring Local Employees in China: Chinese Taxes and Social Insurances. Available at: https:// www.1421.consulting/2018/06/chinese-taxes-and-social-insurances/, accessed 19.03.2019.

Vlasova V.V., Gershman M.A., Kuznetsova T.E., Roud V.A. (2018) Delovoj klimat v nauke: effektivnost' mer nauchnotekhnologicheskoi politiki. Informatsionnyi byulleten' (ekspress-informatsiya), seriya "Nauka, tekhnologii i innovatsii” [The business climate in science: The effectiveness of measures of scientific and technological policy. Newsletter (express information), Series "Science, Technology and Innovation"], Moscow: HSE ISSEK. Available at: https://issek.hse.ru/ data/2018/08/27/1154686176/NTI_N_99_29082018.pdf, accessed 18.03.2019 (in Russian).

Xu J. (2017) The Role of China in the UK Relative Imports from Three Selected Trading Regions: The Case of Textile Raw Material Industry. International Journal of Environmental Research and Public Health, vol. 14, no 12, article 1481 (online). Available at: https://pdfs.semanticscholar.org/e381/0a61703eeaf35c85e7f1fdfd4021cfcc69c9.pdf, accessed 24.04.2019.

Zhukova K., Novyi V. (2019) Routery prokachayut poshlinami. Otechestvennykh proizvoditelej zashchityat ot inostrannykh [Routers pump over duties. Domestic manufacturers will get protection in the face of foreign counterparts]. Kommersant Newspaper, no 5, p. 7. Available at: https://www.kommersant.ru/doc/3854169, accessed 11.03.2019 (in Russian). 